\title{
Effect of Partially-burnt Paddy Husk as a Supplementary Source of Potassium on Growth and Yield of Turmeric (Curcuma longa L.) and Soil Properties
}

\author{
Jude Isuru Wickramasinghe ${ }^{1}$ and Christina Shanthi De \\ Silva ${ }^{2 *}$ \\ ${ }^{1}$ Intercropping and Betel Research Station, Dampelessa, Narammala, Sri \\ Lanka \\ ${ }^{2}$ Department of Agricultural and Plantation Engineering, The Open \\ University of Sri Lanka, Nawala, Sri Lanka
}

\section{Abstract}

An experiment was conducted at the Intercropping and Betel Research Station, Narammala, Dampelessa to study the effects of partially-burnt paddy husk as a supplementary source of potassium on growth and yield of turmeric (Curcuma longa.L) and soil properties during the year 2017. Seven treatments were prepared by using two sources of potassium, namely Muriate of Potash (MOP) and Partially Burnt Paddy Husk (PBPH). The treatments included T1 (zero potassium fertilizer as control), T2 (recommended rate of MOP 100\%), T3 (75\% MOP+25\% PBPH), T4 (50\% MOP+50\% PBPH), T5 (25\% $\mathrm{MOP}+75 \% \mathrm{PBPH})$, T6 (PBPH alone 100\%) and $\mathrm{T} 7$ (recommended rate of $100 \% \mathrm{MOP}+50 \% \mathrm{PBPH})$. For treatment, the percentages of MOP and partially-burnt paddy husk were calculated based on weight

\footnotetext{
* Corresponding should be addressed to Prof. C. S. De Silva, Department of Agricultural and Plantation Engineering, The Open University of Sri Lanka, Nawala, Sri Lanka.
}

Email: csdes@ou.ac.lk

(D)htps://orcid.org/0000-0003-3517-6914

(Received 22 $2^{\text {nd }}$ January 2018; Revised 12th October 2018; Accepted 26 th $^{\text {th }}$ October 2018) (C) OUSL

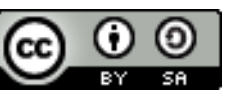

This article is published under the Creative Commons Attribution-Share Alike 4.0 International License (CC-BY-SA). This license permits use, distribution and reproduction in any medium; provided it is licensed under the same terms and the original work is properly cited. 
basis. This experiment was laid out in a Randomized Complete Block Design with three replications. Local type of turmeric was used as planting material and data were collected on soil, growth and yield parameters of turmeric. Parameters were recorded at monthly intervals after planting. Results revealed that most of the growth and yield parameters have increased in a similar pattern $(\mathrm{T} 7>\mathrm{T} 2=\mathrm{T} 3>\mathrm{T} 4>\mathrm{T} 5>\mathrm{T} 6>\mathrm{T} 1)$. Soil parameters also showed significant differences among the treatments due to the application of PBPH. Quality of the rhizome was evaluated based on colour intensity of the rhizome. There was no significant difference between treatments using colour intensity, except in control treatment (T1). The results obtained by the study showed that combined use of MOP $(100 \%)$ with $\mathrm{PBPH}(50 \%)$ has beneficial effects on turmeric cultivation. Therefore partially- burnt paddy husk can be used as a supplementary source of $\mathrm{K}$ for turmeric cultivation to maximize the yield.

Key words: Turmeric, Potassium, partially burnt paddy husk, Fertilizer

\section{Introduction}

Curcuma longa L. (Turmeric) is a perennial rhizomatous herb which belongs to Zingiberaceae family. Turmeric is widely used worldwide as a medicine, condiment, dye, and disinfectant and cosmetic. Due to its economic importance, 800000 tons of turmeric is annually produced in the world, but Sri Lanka only produces 8304 tons (DEA, 2012). Furthermore, there is a good local and export market for turmeric which is grown in Sri Lanka because of its higher curcumin level, especially for organically cultivated turmeric (DEA, 2012). Sri Lanka has the potential to expand turmeric cultivation and earn foreign exchange.

Annually 15-20 tons of turmeric yields can be obtained from 1 ha of turmeric cultivation (DEA, 2012). It removes considerable amounts of nutrients from the field.Fertilizer application is essential in order to obtain a sustainable yield from the field and also previous researches have shown that turmeric plant is sensitive for organic manure and potassium fertilizer (DEA, 2012).

\section{Problem statement}

Farmers use higher amount of potassium fertilizer than other fertilizer for turmeric cultivation because turmeric plants show a positive response to it (Amarawansha, 2006). There are several disadvantages of using an inorganic fertilizer, including the increased cost of production. Government is involved in a programme to minimize the utilization of inorganic fertilizer and to promote organic 
farming (Ministry of Agriculture, 2012) due to the unpopularity of agrochemicals due to perceived health hazards. Therefore, the demand for organic food products has increased. There is a good demand for organically-cultivated turmeric in local and export markets but the production is insufficient. It is important to study the effect of locally available low-cost materials which can be used as supplementary sources of potassium to reduce the total dependence on inorganic fertilizer in turmeric cultivation. It will help to improve organic turmeric cultivation in Sri Lanka. Lack of research and extension programs on organic farming is the principal constraint to the development of productive and profitable organic farming in Sri Lanka (Sangakkara \& Katupitiya., 1989).

\section{Research justification}

Partially-burnt paddy husk is a locally available low-cost organic material which can be used as a supplementary source of potassium. Partially-burnt paddy husk contains a higher amount of potassium when compared to the organic material (Alwis, 2004). The other benefit of adding partially-burnt paddy husk is its good water holding capacity which helps to retain soil moisture enabling cultivation to proceed even under drought conditions (Amarawansha, 2006). Therefore, the objectives of this study are to investigate the merits/demerits of partially-burnt paddy husk as a supplementary source of potassium for growth, yield and quality of turmeric and on soil parameters.

\section{Materials and Methodology}

\section{Location}

The study was conducted at a field belonging to the Intercropping and Betel Research Station, Department of Export Agriculture, Narammala, Dampelessa.

\section{Treatments}

Table 1 shows the seven treatments prepared using two sources of potassium: Muriate of Potash (MOP) and partially-burnt paddy husk (PBPH). Each of the treatment description is given in Table 1. Percentages of Muriate of Potash (MOP) and the partially burnt paddy husk (PBPH) were decided based on DEA (2012) recommendations. 
Table 1. Treatment description

\begin{tabular}{|l|c|c|c|c|}
\hline \multicolumn{1}{|c|}{ Treatment } & $\begin{array}{c}\text { MOP } \\
\text { amount } \\
\left(\mathbf{g} / \mathbf{m}^{2}\right) \\
(\%)\end{array}$ & $\begin{array}{c}\text { Partially } \\
\text { burnt } \\
\text { paddy } \\
\text { husk } \\
\text { amount } \\
\left.\text { (g/m } \mathbf{m}^{2}\right)\end{array}$ & \multicolumn{2}{|c|}{$\begin{array}{c}\text { Amount of DEA } \\
\text { recommended } \\
\text { potassium requirement } \\
\text { supply by potassium } \\
\text { sources g/m }\end{array}$} \\
\hline T1 (Control) & - & - & - & - \\
\hline $\begin{array}{l}\text { T2 } \\
\text { (DEA } \\
\text { recommendation) }\end{array}$ & 20 & - & 100 & - \\
\hline T3 & 15 & 230 & 75 & 25 \\
\hline T4 & 10 & 450 & 50 & 50 \\
\hline T5 & 5 & 680 & 25 & 75 \\
\hline T6 & - & 900 & - & 100 \\
\hline T7 & 20 & 450 & 100 & 50 \\
\hline
\end{tabular}

\section{Experimental design}

One factor in the RCBD with three replicates were used as the design. The field layout is given below.

\section{Land preparation}

Land was cleared, ploughed and after that harrowing was done.

Twenty-one beds having dimensions of $2.4 \mathrm{~m}$ in length and $1.2 \mathrm{~m}$ in width were prepared.

\section{Selection of planting materials and field establishment}

Well matured rhizomes of local type of turmeric, free from pests and diseases were selected. 35-40g parts of rhizomes (seed turmeric rhizomes) were treated with commended fungicide (Mancoseb) and established in the field.

\section{Fertilizer application}

Partially-burnt paddy husk was prepared by controlled burning. Total amount of partially-burnt paddy husk of each treatment was applied with recommended TSP amount as basal application before field establishment of rhizomes. First application of the MOP amounts of each treatment was done with recommended urea amounts, 45 days 
after planting. Second application of MOP with recommended urea amount was done 90 days after planting.

\section{Irrigation}

Plants were watered daily during germinating period except in rainy days. Watering was done manually. In rainy days once a week watering was done to fulfill $1 / 5$ amount of field capacity of the soil. Volume basis method was used to determine the field capacity of one pot.

\section{Data collection}

Data were collected 1, 2, 3, 4, 5 and 6 months after planting based on plant parameters and soil parameters. Plant parameters were measured using randomly selected two plants from each replicate. Quality parameter of the rhizome was evaluated six months after planting.

One month after planting, only plant height and number of emerged plants were measured as plant parameters as the plants were sprouting at that stage.

Data were collected based on plant parameters and soil parameters according to the following methods. Plant parameters are given in Table 2 . 
Table 2. Methods of measuring plant parameters

\begin{tabular}{|c|c|}
\hline Parameter & Method \\
\hline Plant height & $\begin{array}{l}\text { Taken from the ground level to the tip of the } \\
\text { longest shoot. }\end{array}$ \\
\hline $\begin{array}{l}\text { Number of plants } \\
\text { emerged from the } \\
\text { soil }\end{array}$ & Counted in each replicate. \\
\hline $\begin{array}{l}\text { Number of leaves } \\
\text { per clump }\end{array}$ & $\begin{array}{l}\text { Counted in randomly selected two plants from } \\
\text { each replicate. }\end{array}$ \\
\hline Stem diameter & $\begin{array}{l}\text { Measured by using a Vernier Caliper at the top, } \\
\text { middle, and bottom of stem and the average was } \\
\text { calculated and expressed in centimeters. }\end{array}$ \\
\hline $\begin{array}{l}\text { Fresh and dry } \\
\text { weight of the } \\
\text { rhizome }\end{array}$ & $\begin{array}{l}\text { Rhizome was cleaned and the fresh weight } \\
\text { immediately measured while dry weight was } \\
\text { obtained by keeping the rhizome at } 70^{\circ} \mathrm{C} \text { until a } \\
\text { constant weight was seen. }\end{array}$ \\
\hline $\begin{array}{l}\text { Number of rhizome } \\
\text { fingers }\end{array}$ & $\begin{array}{l}\text { Two rhizomes were taken from each replicate and } \\
\text { the numbers of rhizome fingers were counted. }\end{array}$ \\
\hline $\begin{array}{l}\text { Fresh total biomass } \\
\text { weight }\end{array}$ & $\begin{array}{l}\text { Two plants from each replicate were taken and } \\
\text { fresh weight of the total plant was immediately } \\
\text { measured by using electronic balancer. }\end{array}$ \\
\hline Number of roots & Counted using two plants from each replicate. \\
\hline $\begin{array}{l}\text { Quality of the } \\
\text { rhizome }\end{array}$ & $\begin{array}{l}\text { Color intensity of the rhizome was measured using } \\
\text { a spectrophotometer (CT- } 5100 \text { UV/VIS } \\
\text { Spectrophotometer). Pure turmeric juice samples } \\
\text { (3ml) were prepared using } 25 \mathrm{~g} \text { of fresh turmeric } \\
\text { rhizome from each sample. The wave length at } \\
\text { which maximum absorbance ( } \lambda \text { max) took place in } \\
\text { UV detector ( } 430 \mathrm{~nm} \text { ) was selected for further } \\
\text { analysis. The absorbance of each sample was then } \\
\text { measured at } 430 \mathrm{~nm} \text { against distilled water as } \\
\text { blank. Six samples were analyzed for each } \\
\text { treatment and the mean values of absorbance were } \\
\text { taken to compare color intensity of rhizomes. }\end{array}$ \\
\hline
\end{tabular}

\section{Soil parameters}

(i) $\quad \mathrm{N}, \mathrm{P}, \mathrm{K}$ content of soil samples

$\mathrm{N}$ and $\mathrm{K}$ content of soil samples were measured using the Kjeldahl method and Ammonium Acetate extraction method at the Cinnamon Research Station Matara. P content of soil samples was measured using the Vandatemolybdate method at the Soil and Water Laboratory of the Department of Agricultural and Plantation Engineering, The Open University of Sri Lanka. 
(ii) Soil moisture content

Two soil samples were taken from each replicate by using a soil core sampler at $10-30 \mathrm{~cm}$ depths. Wet weights of the soil samples were taken and samples were kept at $105^{\circ} \mathrm{C}$ temperature in oven until weight became constant. The dry weight was subtracted from wet weight to obtain moisture content of the soil and then it was converted to a percentage.

(iii) Soil $\mathrm{pH}$ and Soil EC

Soil $\mathrm{pH}$ was measured using a $\mathrm{pH}$ meter. Soil EC was measured using the HANNA digital EC meter.

\section{Data analysis}

All of above-mentioned data were subjected to Analysis of Variance (ANOVA) using the SAS software package. Mean separation was done by Least Significant Difference Test (LSDT) at 0.05 level of probability.

\section{Results and Discussion}

\section{Soil parameters}

\section{Soil moisture content}

During every month the highest moisture content percentage was observed in treatments T5 (75\% PBPH+25\%MOP) and T6 $(100 \% \mathrm{PBPH})$ and the lowest moisture content percentage was observed in the treatment T1 (Control) and T2 (100\% MOP). Significantly, the highest percentage of moisture content was observed in treatment T6 (100\% PBPH) and the lowest value in treatment $\mathrm{T} 1$ (Control) at the sixth month (Table 3). However, there is no significant difference between treatment T6 and T5 at the sixth month. Moisture content has increased in accordance with the amounts of partially-burnt paddy husk applied. The reason may be the higher water holding capacity of partially-burnt paddy husk (Amarawansha, 2006).

\section{Soil EC}

The highest EC values were observed in the $2^{\text {nd }}$ month probably due to the first application of inorganic fertilizer at 45 days after planting. Significantly highest EC value was observed in treatment T7 $100 \%$ $\mathrm{MOP}+50 \% \mathrm{PBPH}$ ) and the lowest EC value was observed in treatment T6 (Table 3) at the sixth month. Treatment T7 is significantly different from treatment $\mathrm{T} 6$ but not significantly different from treatment T2 (100\% MOP). Initial PBPH sample showed higher EC value of 2.21 and $\mathrm{PBPH}$ may have an effect on soil EC alone but Lehmann and 


\section{J. I. Wickramasinghe \& C. S. De Silva}

Joseph (2009) reported that biochar increases nutrient retention on the top soil by lowering the amount of nutrient leached into lower layers of soil or into ground water and it supports the result of T7 having higher EC than T6.

Table 3. Soil parameters measured at the sixth month afterplanting

\begin{tabular}{|c|c|c|c|c|c|c|}
\hline Treatments & $\begin{array}{l}\text { Soil } \\
\text { Moisture } \\
\text { Content } \\
\quad(\%)\end{array}$ & $\begin{array}{l}\text { Soil electrical } \\
\text { conductivity } \\
(\mathrm{ms} / \mathrm{m})\end{array}$ & $\begin{array}{l}\text { Soil } \\
\text { pH }\end{array}$ & $\begin{array}{c}\text { Soil } N \\
(\%)\end{array}$ & $\begin{array}{l}\text { Soil P } \\
\text { (ppm) }\end{array}$ & $\begin{array}{c}\text { Soil K } \\
(\%)\end{array}$ \\
\hline $\mathrm{T} 1$ (Control) & $4.87^{\mathrm{d}}$ & $0.5^{\mathrm{de}}$ & $6.41^{\mathrm{cd}}$ & $0.17 \mathrm{a}$ & $285^{a}$ & $0.012^{\mathrm{e}}$ \\
\hline $\begin{array}{l}\text { T2 } \\
\text { (100\%MOP). }\end{array}$ & $5.12^{\mathrm{d}}$ & $1.0^{\mathrm{ab}}$ & $6.28 \mathrm{~d}$ & $\begin{array}{l}0.18 \\
\mathrm{a}\end{array}$ & 289 a & $0.025^{a b}$ \\
\hline $\begin{array}{l}\text { T3 } \\
\text { (75\% MOP } \\
+25 \% \text { PBPH) }\end{array}$ & $8.94^{c}$ & $0.9 \mathrm{bc}$ & $6.53^{b c d}$ & $\begin{array}{l}0.18 \\
\mathrm{a}\end{array}$ & $290^{a}$ & $0.024 a b c$ \\
\hline $\begin{array}{l}\text { T4 } \\
\text { (50\% MOP + } \\
50 \% \mathrm{PBPH}\end{array}$ & $10.65^{b}$ & $0.73^{c}$ & $6.7 \mathrm{abc}$ & $\begin{array}{l}0.17 \\
\mathrm{a}\end{array}$ & $276^{a}$ & $0.021 \mathrm{bcd}$ \\
\hline $\begin{array}{l}\text { T5 } \\
(75 \% \mathrm{PBPH}+ \\
25 \% \mathrm{MOP}) \\
\end{array}$ & $15.65^{\mathrm{a}}$ & $0.7 \mathrm{~cd}$ & $6.73^{\mathrm{ab}}$ & $\begin{array}{l}0.18 \\
\mathrm{a}\end{array}$ & 300 a & 0.017 ade \\
\hline $\begin{array}{l}\text { T6 } \\
\text { (100\% PBPH) }\end{array}$ & $15.8^{\mathrm{a}}$ & $0.4 c$ & $6.84^{a}$ & $\begin{array}{l}0.18 \\
\mathrm{a}\end{array}$ & 294 a & $0.016 \mathrm{de}$ \\
\hline $\begin{array}{l}\text { T7 } \\
\text { (100\%MOP+ } \\
50 \% \text { PBPH) }\end{array}$ & $10.66^{b}$ & $1.2^{\mathrm{a}}$ & $6.68 \mathrm{abc}$ & $\begin{array}{l}0.18 \\
\mathrm{a}\end{array}$ & $298^{a}$ & $0.029 a$ \\
\hline
\end{tabular}

\section{Soil pH}

Soil $\mathrm{pH}$ showed decreasing trend from the $1^{\text {st }}$ month up to the $6^{\text {th, }}$ but when compared with the initial value of soil $\mathrm{pH}$ (6.26), $\mathrm{pH}$ values have slightly increased (Table 3). Initial PBPH sample showed higher $\mathrm{pH}$ value of (8.1). Application of partially-burnt paddy husk increases soil $\mathrm{pH}(\mathrm{AICOAF}, 2001)$ and this may be the reason for the increased $\mathrm{pH}$ values in treatments.

In the sixth month the highest $\mathrm{pH}$ value was observed in treatment T6 (100\% PBPH) and the lowest $\mathrm{pH}$ value in treatment T2 (100\% MOP) (Table 3). Treatment T6 is significantly different from treatment T2. $\mathrm{pH}$ values of treatments with higher amount of PBPH (T5 and T6) have shown significant differences from the treatments which did not involve PBPH (T1 and T2). Reason for the decreasing trend of $\mathrm{pH}$ values may be due to the application of urea, 45 days and 90 days after planting and soil $\mathrm{pH}$ decreases after application of the urea due to acidification resulting from dissociation of urea to produce $\mathrm{H}^{+}$ions. 


\section{Available Nitrogen}

There is no significant difference among the treatments applied to soil with available nitrogen six months after planting (Table 3), but when compared to the available $\mathrm{N}$ in the initial soil $(0.16 \%), \mathrm{N}$ values of all the treatments have slightly increased. The reason for the increased $\mathrm{N}$ level may be due to the application of urea, 45 and 90 days after planting. All the treatments received equal amounts of nitrogen fertilizer (urea) in the same manner and this may be the reason for no significant differences among the treatments.

\section{Available Phosphorus}

There is no significant difference among the treatments applied to soil with available phosphorus six months after planting (Table 3), but when compared to the initial soil available $P$ value (270ppm), P values of all the treatments have slightly increased. The reason for the increased P level may be due to the application of TSP, 45 and 90 days after planting. All the treatments received equal amount of phosphorus fertilizer (TSP) in the same manner and this may be the reason for no significant differences among the treatments.

\section{Available Potassium}

Soil with available potassium shows significant differences among treatments six months after planting (Table 3), but when compared to the initial soil potassium content $(0.015 \%)$, potassium content of all the treatments, except $\mathrm{T} 1$ (Control), have increased slightly (Table 3 ). The reason for the increased potassium levels may be due to the potassium fertilizers and PBPH contained in those treatments. In the $6^{\text {th }}$ month the highest available potassium value was observed in treatment $\mathrm{T} 7(100 \% \mathrm{MOP}+50 \% \mathrm{PBPH})$ and the lowest available was observed in treatment T1 (Control). Treatment T7 is significantly different from treatment T1. Treatment T7 contained the highest amount of potassium and treatment $\mathrm{T} 1$ contained no potassium. This may be the reason for the above observation. The reason for the variation of potassium content among the other treatments may be due to the different ratios of potassium sources (MOP: PBPH) contained in the individual treatments.

\section{Growth parameters}

\section{Number of emerged plants}

Number of emerged plants showed an increasing trend. Treatment T6 $(100 \%$ PBPH) showed the significantly highest number of emerged plants in the $1^{\text {st }}$ and the $2^{\text {nd }}$ months. Treatments T1 (Control) and T2 $(100 \% \mathrm{MOP})$ have showed the lowest number of emerged plants. In 


\section{J. I. Wickramasinghe \& C. S. De Silva}

the second month, treatment T6 showed the significantly highest number of emerged plants (Table 4). There is a significant difference between treatments which have applied PBPH and treatments which have not. Soil moisture is important for germination and soil moisture content vary depending on the amount of added partially-burnt paddy husk. Treatment T6 contains the highest amount of PBPH and it may be the reason for the highest number of emerged plants.

\section{Plant height}

Plant height showed an increasing trend from the 1st month up to $6^{\text {th }}$. Plant height has increased in a similar pattern as follows: $\mathrm{T} 7>\mathrm{T} 2=\mathrm{T} 3>\mathrm{T} 4>\mathrm{T} 5>\mathrm{T} 6>\mathrm{T} 1$. Significantly the highest plant height was observed in treatment T7 $(50 \% \mathrm{PBPH}+100 \% \mathrm{MOP})$ and the lowest was observed in treatment $\mathrm{T} 1$ (Control) the sixth month (Table 4). Treatment $\mathrm{T} 7$ is significantly different from treatment $\mathrm{T} 1$. The reason for the increasing trend of plant height may be due to the quick response in the application of inorganic fertilizer, 45 days and 90 days after planting. The plant height has increased proportionally to the amount of MOP contained in the treatments. Noor et al (2014) have reported that the increased plant height in turmeric crop could be due to increasing $\mathrm{K}$ fertilizer. Treatments $\mathrm{T} 2$ and T7 contains the same amount of MOP, but the additional amount of PBPH in treatment T7 may be the reason for the significant difference between treatments T2 and T7. Furthermore, treatment T6 (100\%PBPH) showed higher plant height than treatment T1 (Control) because treatment T6 has PBPH and Graber (2010) has reported increased plant height in tomato crop due to biochar application.

Table 4. Growth parameters measured on the 6th month afterplanting.

\begin{tabular}{|l|l|l|l|l|}
\hline Treatments & $\begin{array}{l}\text { Emerged } \\
\text { plants }(\%)\end{array}$ & $\begin{array}{l}\text { Plant } \\
\text { height } \\
\text { (cm) }\end{array}$ & $\begin{array}{l}\text { Number of } \\
\text { Leaves }\end{array}$ & $\begin{array}{l}\text { Stem } \\
\text { diameter } \\
\text { (cm) }\end{array}$ \\
\hline T1(Control) & $56.3^{\mathrm{c}}$ & $127.7^{\mathrm{d}}$ & $9.3^{\mathrm{d}}$ & $2.6^{\mathrm{d}}$ \\
\hline $\begin{array}{l}\text { T2 } \\
(100 \% \mathrm{MOP}) .\end{array}$ & $59.4^{\mathrm{c}}$ & $149.4^{\mathrm{b}}$ & $11.0^{\mathrm{b}}$ & $3.2^{\mathrm{b}}$ \\
\hline $\begin{array}{l}\text { T3 } \\
(75 \% \mathrm{MOP}+25 \% \mathrm{PBPH})\end{array}$ & $71.9^{\mathrm{b}}$ & $148.8^{\mathrm{b}}$ & $10.8^{\mathrm{bc}}$ & $3.1^{\mathrm{b}}$ \\
\hline $\begin{array}{l}\text { T4 } \\
(50 \% \mathrm{MOP}+50 \% \mathrm{PBPH}\end{array}$ & $75^{\mathrm{b}}$ & $139.5^{\mathrm{c}}$ & $10.0^{\mathrm{bc} \mathrm{d}}$ & $2.9^{\mathrm{c}}$ \\
\hline $\begin{array}{l}\text { T5 } \\
(75 \% \mathrm{PBPH}+25 \% \mathrm{MOP})\end{array}$ & $78.1^{\mathrm{b}}$ & $137.9^{\mathrm{c}}$ & $9.8^{\mathrm{bc} \mathrm{d}}$ & $2.9^{\mathrm{c}}$ \\
\hline $\begin{array}{l}\text { T6 } \\
(100 \% \mathrm{PBPH})\end{array}$ & $90.6^{\mathrm{a}}$ & $136.7^{\mathrm{c}}$ & $9.7^{\mathrm{cd}}$ & $2.9^{\mathrm{c}}$ \\
\hline $\begin{array}{l}\text { T7 } \\
(100 \% M O P+50 \% \mathrm{PBPH})\end{array}$ & $75^{\mathrm{b}}$ & $157^{\mathrm{a}}$ & $12.3^{\mathrm{a}}$ & $3.5^{\mathrm{a}}$ \\
\hline
\end{tabular}




\section{Number of leaves}

The number of leaves showed an increasing trend from the $2^{\text {nd }}$ month up to the $6^{\text {th }}$. Significantly the highest number of leaves was observed in treatment $\mathrm{T} 7(50 \% \mathrm{PBPH}+100 \% \mathrm{MOP})$ and the lowest in treatment T1 (Control) on the sixth month (Table 4). Treatment T7 is significantly different from treatment $\mathrm{T} 1$. The reason for the above observation may be due to the quick response of application of inorganic fertilizer, 45 days and 90 days after planting.

The number of leaves has increased proportionally to the amount of MOP contained in the treatments. Annie et al (2002) have recorded increased number of leaves in turmeric crop due to increasing potassium fertilizer. Treatments $\mathrm{T} 2$ and $\mathrm{T} 7$ contained the same amount of MOP but the additional amount of PBPH in treatment T7 may be the reason for the significant difference between treatments $\mathrm{T} 2$ and $\mathrm{T} 7$.

\section{Pseudo diameter}

Pseudo stem diameter showed an increasing trend from the $2^{\text {nd }}$ month up to the $6^{\text {th }}$. Significantly the highest pseudo stem diameter was observed in treatment T7 $(50 \% \mathrm{PBPH}+100 \% \mathrm{MOP})$ as shown in Table 4. The reason for the above observation may be due to the quick response in the application of inorganic fertilizer, 45 days and 90 days after planting. Pseudo stem diameter has increased proportionally to the amount of MOP contained in the treatments. Annie et al (2002) have recorded an increased pseudostem girth in turmeric crop correlating with the $\mathrm{K}$ fertilizer level.

\section{Yield Parameters}

\section{Number of rhizome fingers}

The number of rhizome fingers shows an increasing trend from the $2^{\text {nd }}$ month up to the $6^{\text {th }}$ month. The number of rhizome fingers has increased in a similar pattern as follows: $\mathrm{T} 7>\mathrm{T} 2=\mathrm{T} 3>\mathrm{T} 4>\mathrm{T} 5>\mathrm{T} 6>\mathrm{T} 1$ (Table 5). Treatment T7 is significantly different from treatment T1. The reason for the above observation may be due to the quick response of the application of inorganic fertilizer, 45 days and 90 days after planting. The number of rhizome fingers has increased proportionally to the amount of MOP contained in the treatments. Annie et al. (2002), Karthikeyanet al. (2009) have recorded increased number of rhizome fingers in turmeric crop due to increased $\mathrm{K}$ fertilizer. 
Table 5. Yield parameters measured on the 6th month after planting

\begin{tabular}{|l|l|l|l|l|}
\hline Treatments & $\begin{array}{l}\text { Number of } \\
\text { rhizome } \\
\text { fingers }\end{array}$ & $\begin{array}{l}\text { Fresh } \\
\text { weight of } \\
\text { rhizome } \\
\text { (g) }\end{array}$ & $\begin{array}{l}\text { Dry weight } \\
\text { of rhizome } \\
\text { (g) }\end{array}$ & $\begin{array}{l}\text { Fresh } \\
\text { Biomass } \\
\text { weight of } \\
\text { plant (g) }\end{array}$ \\
\hline T1(Control) & $11.5^{\mathrm{d}}$ & $139.5^{\mathrm{d}}$ & $18.1^{\mathrm{d}}$ & $339.5^{\mathrm{d}}$ \\
\hline $\begin{array}{l}\text { T2 } \\
(100 \% \mathrm{MOP})\end{array}$ & $14.0^{\mathrm{b}}$ & $172.1^{\mathrm{b}}$ & $22.4^{\mathrm{b}}$ & $372.1^{\mathrm{b}}$ \\
\hline $\begin{array}{l}\text { T3 } \\
(75 \% \mathrm{MOP}+25 \% \mathrm{PBPH})\end{array}$ & $13.9^{\mathrm{b}}$ & $171.3^{\mathrm{b}}$ & $22.3^{\mathrm{b}}$ & $371.3^{\mathrm{b}}$ \\
\hline $\begin{array}{l}\text { T4 } \\
(50 \% \mathrm{MOP}+50 \% \mathrm{PBPH}\end{array}$ & $13.0^{\mathrm{c}}$ & $164.2^{\mathrm{c}}$ & $21.3^{\mathrm{c}}$ & $364^{\mathrm{c}}$ \\
\hline $\begin{array}{l}\text { T5 } \\
(75 \% \mathrm{PBPH}+25 \% \mathrm{MOP})\end{array}$ & $13.0^{\mathrm{c}}$ & $163.5^{\mathrm{c}}$ & $21.3^{\mathrm{c}}$ & $363.5^{\mathrm{c}}$ \\
\hline $\begin{array}{l}\text { T6 } \\
(100 \% \mathrm{PBPH})\end{array}$ & $12.7^{\mathrm{c}}$ & $162.5^{\mathrm{c}}$ & $21.1^{\mathrm{c}}$ & $362.4^{\mathrm{c}}$ \\
\hline $\begin{array}{l}\text { T7 } \\
(100 \% \mathrm{MOP}+50 \% \mathrm{PBPH})\end{array}$ & $15.0^{\mathrm{a}}$ & $177.6^{\mathrm{a}}$ & $23.1^{\mathrm{a}}$ & $377.6^{\mathrm{a}}$ \\
\hline
\end{tabular}

\section{Fresh weight of the rhizome}

Fresh weight of the rhizome showed an increasing trend from the $2^{\text {nd }}$ month up to the $6^{\text {th }}$. The fresh weight of the rhizome has increased in a similar pattern as follows: $\mathrm{T} 7>\mathrm{T} 2=\mathrm{T} 3>\mathrm{T} 4>\mathrm{T} 5>\mathrm{T} 6>\mathrm{T} 1$ (Table 5). Significantly the highest fresh weight of rhizome $(177.6 \mathrm{~g})$ was observed in treatment T7 and the lowest weight $(139.5 \mathrm{~g})$ in control treatment T1. The reason for the above observation may be due to the quick response of the application of inorganic fertilizer, 45 days and 90 days after planting. The fresh weight of rhizome has increased proportionally to the amount of MOP in the treatments. This result agrees with the results of Annie et al (2002) as the fresh weigh increased with increased potassium fertilizer. Furthermore, fresh weight of the rhizome has increased according to the method of using, zero fertilizer (T1) < organic fertilizer alone (T6) < chemical fertilizer alone (T2) < combined use of organic and chemical fertilizer (T7). These results agree with the results of HARTI (2013).

\section{Dry weight of the rhizome}

The dry weight of the rhizome also followed the same pattern as the fresh weight of rhizomes. The dry weight of the rhizome has increased in a similar pattern to the fresh weight of the rhizome $(\mathrm{T} 7>\mathrm{T} 2=\mathrm{T} 3>\mathrm{T} 4>\mathrm{T} 5>\mathrm{T} 6>\mathrm{T} 1$ (Table 5). The significantly highest dry weight of rhizome $(23.1 \mathrm{~g})$ was observed in T7 with $100 \%$ MOP and $50 \%$ of PBPH. The lowest dry weight of rhizome (18.1g) was observed in control treatment $\mathrm{T} 1$. The reason for the above observations may 
be due to the quick response of the application of inorganic fertilizer, 45 days and 90 days after planting. Dry weight of the rhizome has increased proportionally to the amount of MOP in the treatments and this result is supported by the results of Karthikeyan et al (2009). PBPH may also have an effect on dry weight of the rhizome. Priyadarshini \& Seran (2009) reported that increased dry weight of cowpea pods due to application of PBPH.

\section{Fresh biomass weight of plant}

The fresh biomass weight showed an increasing trend from the $2^{\text {nd }}$

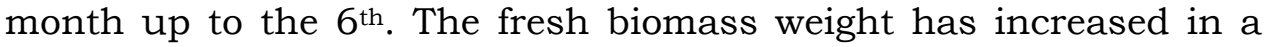
similar pattern as follows: $\mathrm{T} 7>\mathrm{T} 2=\mathrm{T} 3>\mathrm{T} 4>\mathrm{T} 5>\mathrm{T} 6>\mathrm{T} 1$ (Table 5). Significantly the highest fresh biomass weight of plant $(377.6 \mathrm{~g})$ was observed in treatment T7 and the lowest $(339.5 \mathrm{~g})$ in control treatment T1. The reason for the above observations may be due to the quick response of the application of inorganic fertilizer, 45 days and 90 days after planting. The fresh biomass weight of plant has increased proportionally to the amount of MOP in the treatments. Karthikeyan et al. (2009) reported that increasing the application rate of potassium in the form of $\mathrm{KCl}$ enhanced the growth of turmeric. Priyadarshini \& Seran (2009) reported increased fresh biomass weight of cowpea plant except their roots due to the application of PBPH. There may be a combined effect of MOP and PBPH on the fresh biomass weight of turmeric as observed in this study.

\section{Quality parameter}

\section{Colour intensity of the rhizome}

There is a significant difference between treatment T1 (Control) and all the other treatments (T2, T3, T4, T5, T6, T7) (Fig. 1). HARTI (2003) mentioned that the quality of the turmeric rhizome differs with its colour and the reason for the yellow colour of the rhizome is curcumin. These results indicate that there is no significant difference among the treatments on the quality of turmeric except in treatment T1. When compared with all the other treatments, treatment T1 might have contained relatively a lower curcumin amount and all the other treatments might have contained nearly equal amounts of curcumin but higher than the control treatment. This may be due to the fact that treatment $\mathrm{T} 1$ (control) did not contain any potassium source and Akamine et al.(2007) reported that potassium is the principal element involved in curcumin formation in turmeric. 


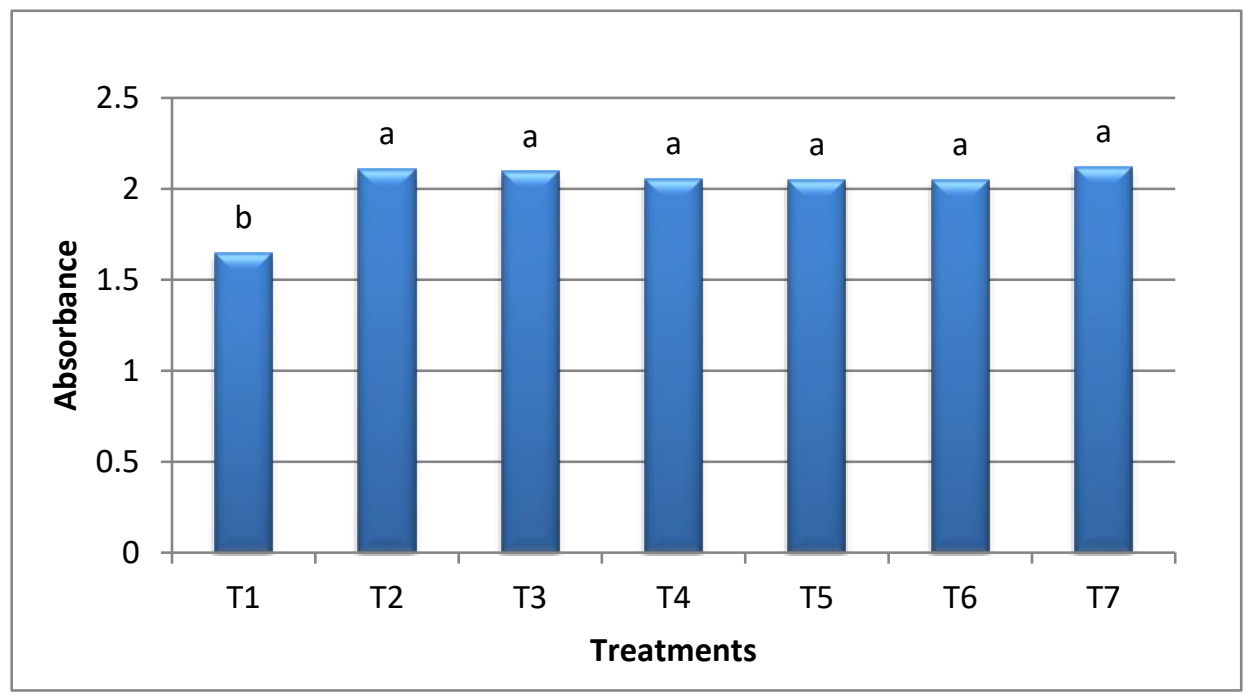

Figure 1. Absorbance of curcumin (means with the same letter is not significantly different)

\section{Conclusions and Recommendations}

According to the above observations, the combined use of MOP with PBPH has shown beneficial effects on turmeric cultivation. Partiallyburnt paddy husk has beneficial effects as a supplementary source of potassium for growth of turmeric and it enhances the effects of MOP on the growth, yield and quality of turmeric. Therefore, farmers are advised to use partially-burnt paddy husk to dissolve and retain inorganic fertilizer in the soil. It also helps to improve the efficiency of applied inorganic fertilizer in order to increase the yield.

\section{Acknowledgements}

Authors gratefully acknowledge Mr. D. M. P. V. Dissanayaka and other staff of the Intercropping and Betel Research Station, Dampelessa, Narammala for the assistance given during this research study.

\section{References}

AICOAF. (2001). Application of rice husk charcoal. Food and Fertilizer Technology Center for the Asian and Pacific region leaflet for Agriculture. Practical technologies 4. Association for international Cooperation in Agriculture and Forestry (AICOAF), Japan. 
Akamine, H., Hossain, A., Ishmine, Y., Yogi, K., Hokama, K., Iraha, Y. \& Aniya, Y. (2007). Effects of application on N, P and K alone or in combination on growth, yield and curcumin content of turmeric (Curcuma Longa L.), Plant Production Science, 10:1, 151-154. DOI: $10.1626 /$ pps.10.151

Alwis, P. A. I. S. D. (2004). Appropriate nutrient management of bell pepper (Capsicum annum L.) under controlled environment agriculture, Final year thesis, Department of Crop Science, Faculty of Agriculture, University of Peradeniya.

Amarawansha, E. A. G. S. (2006). Use of partially burned paddy husk as a component of potting media for Piper niger L. Final year thesis, Department of Crop Science, Faculty of Agriculture, University of Peradeniya.

Annie, T., Swati, B. \& Singh, D. B. (2002). Influence of different levels of nitrogen and potassium on growth and yield of turmeric (Curcuma longa L.). Journal of Spices and Aromatic Crops, 11(1): 74-77(2002).

DEA. (2012). Turmeric cultivation and processing (Technical bulletin) 17, Department of Export Agriculture.

Graber, E. R., Harel, Y. M., Kolton, M., Cytryn, E., Silber, A., David, D. R., Tsechansky, L., Borenshtein, M. \& Elad, Y. (2010). Biochar Impact on Development and Productivity of Pepper and Tomato Grown in Fertigated Soilless Media. Plant Soil, 337, 481-496. DOI/ 10.1007/s 11104-010-0544-6

HARTI. (2013). Research report:54, Hector Kobbekaduwa Agrarian Research and Training Institute. Colombo.

Karthikeyan, P. K., Ravichandran. M., Imas. P. \& Assaraf., M. (2009). The effect of Potassium on the Yield and Quality of Turmeric (Curcuma longa). E-ifc No .21, September 2009.

Lehmann, J. \& Joseph, S. (2009). Biochar for Environmental Management: An Introduction. In Biochar for Environmental Management: Science and Technology. Earthscan Ltd, London. 1-12.

Ministry of Agriculture. (2012). Promotion of Production and Use of Organic Fertilizer [online]. Available at 
www.agrimin.gov.lk/web/index.php/en/project/12project/26-promotion-of-production(Accessed: 18.03.2017)

Noor, S., Akhter, S., Islam, M. S., Hasan, T. \& Hamidullah, A. T. M. (2014). Response of Turmeric (Curcuma longa) to Potassium Fertilization on K Deficient Soil in Northern Bangladesh. Report e-ifc No.37.

Priyadarshani, J. \& Seran., T. H. (2009). Paddy husk ash as a source of potassium for growth and yield of cowpea (Vignaunguiculata L.). Report No 35. Department of Export Agriculture.

Sangakkara, U. R. \& Katupitiya, S. (1989). Organic Farming in Sri Lanka [Online] Available at https://www.researchgate.net/publication/237290591 Organic Farming in Sri Lanka. 